\title{
ON THE ENDURING RELATIONSHIP BETWEEN MASCULINITY AND HOMOPHOBIA
}

\author{
Sarah Diefendorf \\ Scholars Strategy Network Postdoctoral Scholar, University of Utah \\ Tristan Bridges \\ University of California, Santa Barbara
}

(Forthcoming in Sexualities)

\begin{abstract}
Recent research in the social sciences suggests a methodological paradox as scholars work to make sense of the contemporary relationship between masculinity and homophobia.

Representative surveys consistently find dramatically decreasing levels of sexual prejudice among all groups, among men and young men in particular. Qualitative scholarship, however, continues to find that enactments of homophobia remain integral components of contemporary masculine identities. In this article, we make sense of this shift and apparent methodological inconsistency. We do not question which measure is best. Instead, we argue for a need to understand the ways that gendered sexual prejudice transforms in ways that allow the relationship between masculinity and homophobia to endure-sometimes even when it appears to be in decline.
\end{abstract}

Keywords: masculinity, homophobia, masculinities, hegemonic masculinity, sexual prejudice 
Feminist research on gender, sexuality, and inequality began to more critically document a relationship between masculinity, heterosexuality, and prejudice against sexual minorities in the 1970s and 1980s. This early research was primarily quantitative and found that on virtually every measure, men exhibited higher levels of sexual prejudice than women. This was among the earliest ways the relationship between masculinity and heterosexuality was establishedmasculinity as at least partially enacted by and through confessions of sexual prejudice.

This scholarship was among the work that led Raewyn Connell $(1987,1995)$ to suggest that gay men offered an important symbolic configuration of "subordinate masculinity" against which culturally idealized forms of masculinity were positioned (see also Carrigan, Connell, and Lee 1985). Homophobia and sexual prejudice came to be seen as among the central elements of contemporary masculine identities as these practices work to subordinate qualities that help position culturally idealized masculinities as hegemonic (Connell 1992).

Since the turn of the century, however, quantitative evidence suggests a marked decline in sexual prejudice along most measures. And, on some measures, men have started expressing lower levels of sexual prejudice than women. This could imply that the relationship between masculinity and homophobia is declining or weakening. Qualitative scholarship, however, with few exceptions, continues to find that enactments of sexual prejudice remain integral components of masculinity for heterosexual men.

In this article, we make sense of this shift and apparent methodological paradox. Rather than questioning which measure is best, we argue that we need to understand the ways that gendered sexual prejudice is multi-dimensional and transforming and that more work needs to continue to examine the relationship between individual beliefs, prejudice, and actions with structural homophobia. The relationship between masculinity, homophobia, and heterosexuality has shifted over time and continues to do so today. We describe research and theory that collectively illustrate that the processes through which gender and sexual inequalities are maintained have shifted in ways that make them less easily recognizable, but effective in preserving enduring systemic, institutionalized and structural mechanisms involved in the reproduction of inequality.

\section{Connecting Masculinity and Homophobia}

Scholarship on gender and sexual prejudice has long established a connection quantitatively (Herek 1986; Lehne 1976). Relying primarily on survey data, scholars began to note that on virtually every measure of sexual prejudice, men seemed to express more than women. A collection of characteristics is correlated with prejudice against sexuality minorities. For example, in the U.S., Democrats respond to surveys with less sexual prejudice than do Republicans; youth respond with less sexual prejudice than older people; education is negatively correlated with sexual prejudice; certain religious affiliations espouse high levels of sexual prejudice. This list goes on. And within each of these categories, men espouse more sexual prejudice than women.

Consider the ways that Americans have responded to the awkwardly worded question on the General Social Survey over the course of four decades (Figure 1). While not a perfect relationship, the results illustrate patterns in survey research on sexual prejudice. Feminist 
scholars studying men and masculinities sought to make sense of, as Gregory Herek wrote, "the proposition that to be 'a man' in contemporary American society is to be homophobic - that is, to be hostile toward homosexual persons in general and gay men in particular" (1986: 563). Herek was interested in the gendered nature of homophobia. While he discovered little difference (as Figure 1 suggests) between men's and women's attitudes toward homosexuality, larger and more significant differences emerged on surveys asking questions specifically about gay men - a group toward which heterosexual men held much more negative views when compared with women (e.g., Herek 1986; Lehne 1976).

Figure 1. Percentage of Americans Claiming "Sexual Relations between Two Adults of the Same Sex" are "Always Wrong" or "Almost Always Wrong", 1973-2016

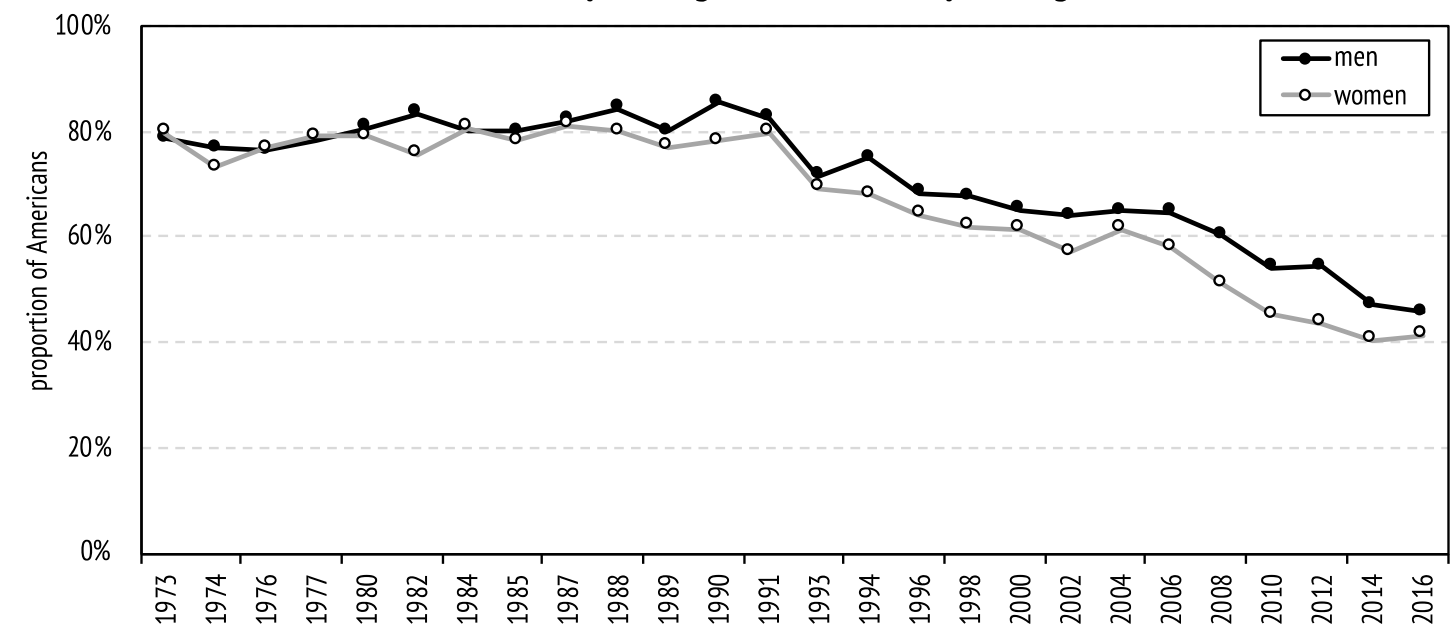

Data Source: General Social Survey, 1973-2016. Available at: https://gssdataexplorer.norc.org/

Some of the earliest meta-analyses showed that while sexual prejudice has declined over time, the gender gap in sexual prejudice has grown (e.g., Kite 1984). Kite (1984) suggested two interpretations. First, homophobic sentiments may have become more gendered over time (a suggestion that makes sense of the growing gap between men's and women's attitudes toward same-sex sexuality on Figure 1). Second, as studies have come to use measurements more reliable and sensitive to this gendered difference, we may simply be better capturing a difference that might have been captured earlier with more precise measurements.

Kite and Whitley (1996) later produced a larger meta-analysis assessing gendered differences in attitudes toward same-sex oriented people, behavior, and rights. Here, they noted that men express more sexual prejudice toward gay people (gay men in particular) and same-sex sexual behavior than women. Though they found no gender differences in support for gay rights, subsequent research has established less support for gay rights among men than women (e.g., Herek 2002; Pew Research Center 2017; Schwartz 2010).

Research continued to document and further refine this more general claim (e.g., LaMar and Kite 1998), and the connection between gender and sexual prejudice has been established crossculturally as well. As gay identities have become more publicly visible around the world, a gender divide persists globally in terms of the support for and rejection of gay people and gay rights. The persistence of sexual prejudice cross-culturally undermines what are often neo- 
colonialist assumptions that homophobia is primarily a problem in "Non-Western" or Southern nations. Puar's $(2007,2013)$ work and theorization of "homonationalism"-a transnational cultural process through which gains in legal rights or recognition for LGBT persons in "the West" are sometimes mobilized to justify forms of sectarianism and xenophobia—provides a powerful critique of Western understandings of homophobia, and, alongside discourses of "change" and "progress," offers an important reminder of both the persistence of homophobia internationally and the raced and nationalistic discourses that also shape assumptions about these patterns.

Figure 2. Proportions of Women and Men Qaiming that 'Homosexuality' is' Never ustifiable" by Country, 2010-2014

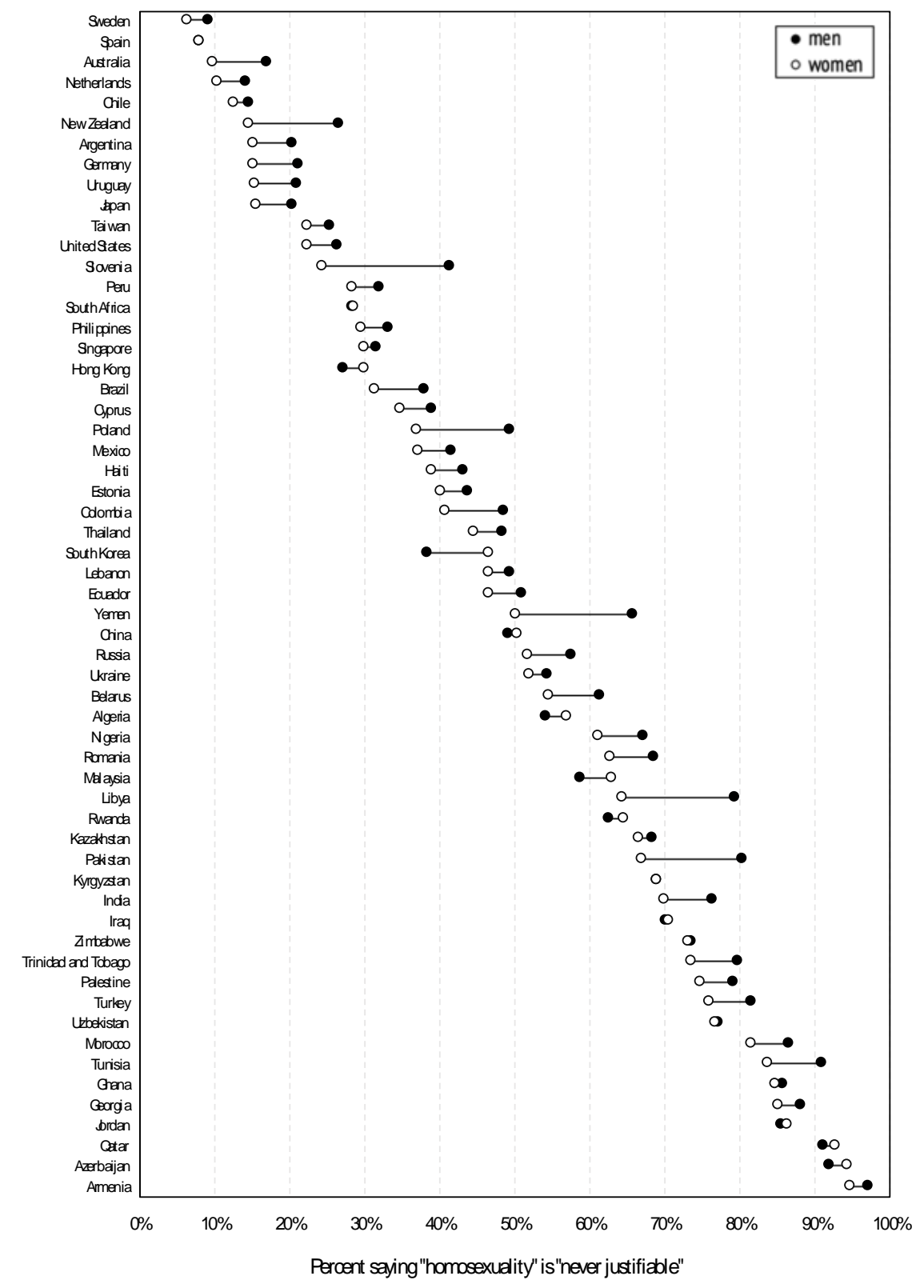

DataSourœ: Wbrld Values Survey, 2010-2014. Availableat: httpj//nww.worldvaluessurvey.org/WWSOnline.jsp. 
In this article, we primarily rely on and review scholarship from the US and the UK; we recommend future research and theorizing better account for the research conducted on the relationship between masculinity and sexual prejudice in other regions (see Epprecht 2013; Flood and Hamilton 2005; M'baye 2013) to consider this relationship on a more global scale. Figure 2 summarizes the results of the World Values Survey's most recent data on societies around the world between 2010 and 2014. Here, individuals were asked to rate "homosexuality" on a 1-10 scale (where 1 is "never justifiable" and 10 is "always justifiable"). Men continue to express more sexual prejudice than women in almost every society surveyed. While containing elements specific to nation and cultural context, men's homophobia is here apparent on a global scale.

Early research relied on these attitudinal differences between men and women to establish a relationship between homophobia/sexual prejudice and masculinity. And this empirical relationship was one of the first ways that some of the early theoretical work within critical masculinities studies connecting masculinity to homophobia emerged as well. It is to that work that we now turn.

\section{Theoretical Explanations}

Early work theorizing masculinities as integral components of gender relations situated sexual prejudice, homophobia, and distinction from gay men as central factors in the production of "hegemonic masculinity" (e.g., Carrigan, Connell, and Lee 1985; Connell 1987, 1995). Indeed, historical research has documented that the construction of masculinities over time often rely on various "countertypes" (Mosse 1996) - the various identities, stereotypes, and archetypes of masculinity against and alongside which culturally valorized masculinities are constructed. Tracing the history of the construction of modern manhood in Europe, Mosse summarizes how specific masculinities were mobilized as counter-types to newly constructed masculine idealsand Jews and gay men were relied upon as key examples, "frightening on the one hand precisely because they were stereotyped, but on the other, because they were assimilated, they could live unrecognized, hiding among the population." (1996: 70-71)

Indeed, historical research in the U.S. documents a similar process (e.g., Chauncey 1994; Ibson 2002; Kimmel 2012). Kimmel (2012) argues that in the U.S., the connection between homophobia with masculinity happened right around the turn of the twentieth century. It was during this time that men began to consider their exclusive sexual desires for women as an integral component of what made them "real men" (see also Chauncey 1994). The construction of an explicitly heterosexual masculinity, however, did not exist prior to homophobia, as some suggested (e.g., Lehne 1989), but rather, was produced alongside it (Connell 1992, 1995; Greenberg 1988; Katz 1990). Here prejudice against sexual minorities is framed as part of the historical construction of an explicitly heterosexual masculinity.

Raewyn Connell $(1987,1992,1995)$ relied on this history and research to argue that gay men illustrated an important example of what she refers to as "subordinate masculinity" (see also Carrigan et al., 1985; Connell, Davis, and Dowsett 1993). Like countertypes, subordinate masculinities play a critical role in the (re)production of gender hegemony and inequality. Indeed, for Connell, hegemonic masculinity achieves hegemonic status through both ideological 
and practical processes of marginalization and subordination. Connell situates gay masculinities not as the only form of subordinated masculinity, but as occupying one of the most conspicuous forms. As such, "Research on masculinity must explore how gender operates for those men most vehemently defined as unmasculine" (Connell 1992: 737; see also Chen 1999).

Research on the relationship between masculinity and homophobia was the subject of a great deal of theoretical and empirical scholarship in the 1980s and 1990s. Indeed, Michael Kimmel's (1994) essay_-"Masculinity as Homophobia"-is among the more cited and reproduced pieces of writing in the field. Kimmel theorized masculinity as a homosocial enactment - a performance produced by and for other men. And, as Lipman-Blumen (1976) argues, homophobia is centrally linked to masculinity in homosocially stratified societies in defining boundaries between social and sexual interaction. Indeed, as Britton (1990) discovered, support for the maintenance of sexsegregated institutions (support for institutionalized homosociality) is, among men, highly correlated with sexual prejudice.

According to Kimmel (1994), masculinity is fraught from the start—requiring risks and unrelenting competition and opposition. Building on psychoanalytic theories of gender, Kimmel (1994) articulates the motivations for and emotions surrounding enactments of masculinity. Here, Kimmel suggests that fear operates as the overriding emotion associated with enactments of masculinity. Sexual prejudice is a consequence of this fear. Kimmel theorizes masculinity as a "flight from the feminine" wherein homoerotic desires are, for boys and men, situated as feminine within a Freudian logic (Kimmel 1994). For Kimmel, masculinity is a defensive posture mobilized against a seemingly ever-present series of perceived threats of humiliation by other men. But the fear itself is not a fear of gay men, but rather of being discovered by other men to be insufficiently masculine.

Pascoe $(2005,2007)$ built on theorizations of the relationship between masculinity and homophobia in ways that have motivated a great deal of subsequent scholarship. Pascoe conducted an ethnographic study of masculinity in a U.S. high school. She was specifically interested in the meanings and uses of the term "fag" among boys in her study. Like Kimmel, Pascoe argued that homophobia works as a form of intra-gender "policing" among boys and men. Pascoe's theorization of the connection between masculinity and homophobia, however, focusses more on the social, interactional, and institutional levels of analysis in comparison to the psychoanalytic frame Kimmel proposed. In so doing, Pascoe demonstrates that homophobia is about much more than sexuality and heterosexism; it is also about gender (misogyny, sexism, and androcentrism) as well as race and racial inequality. She also provided an important exemplar of how homophobia is institutionally embedded and authorized in the school in which she conducted her study. Pascoe argues that "homophobia" is not the right concept to describe the connections described in this essay; she proposes "fag discourse" instead. ${ }^{1}$

In defining what Pascoe terms fag discourse, she argues that research relying on "homophobia" had been overlooking the gendered and racialized nature of fag as a sexualized insult (e.g., Corbett 2001; Plummer 2001). As Pascoe (2007: 54) argues, fag discourse is a disciplinary discourse through which boys and men regulate their own and each other's behavior under the guise of joking interactions. She was particularly interested in the fluid properties of fag identities which made boys continually open to challenge and the ways that the practice was 
implicitly institutionally authorized at the school. Indeed, Pascoe demonstrated the ubiquity of this disciplinary practice during an era in which tolerance for gay people and rights were ostensibly on the rise.

Pascoe suggests that masculinity is produced not only through fag discourse, but through its relationship with what she calls "compulsive heterosexuality" (Pascoe 2007, Rich 1970). Building on Butler's notion of gendered performativity, Pascoe conceptualizes fag discourse as a form of gendered repudiation whereby young men interactionally socialize one another into normatively masculine behaviors, attitudes, and dispositions. Boys and young men participated in sex talk and more that worked to reproduce and eroticize dominance among boys and men over girls and women. This gendered and sexualized form of dominance work interactionally confirms boys' gender identities, but only within the interactional moments in which they occurred. Thus, Pascoe demonstrates sociologically that homophobia has at least as much to do with masculinity as it does with an actual fear of gay men or same-sex intimacy. She theorizes masculinity as reproduced through the dialectical relationship between interactional enactments of confirmation (compulsive heterosexuality) and repudiation (fag discourse).

Pascoe also documents and argues that this repudiation, through the fag discourse, carries racialized meanings. While there are certain behaviors that put all boys at risk for this gender repudiation, Pascoe found that fag discourse was ignored when mobilized by white boys, but punished when enacted by African-American boys. As such, Pascoe joins other scholars who argue that homophobia is not a racially neutral phenomenon (Connell 2016; King 2004; Pascoe 2007). Rather, homophobia is a part of gendered, racialized and sexualized social interactions. Homophobia is less about an individual fear, and instead understood as reflective of and rooted in a larger system of intersecting inequalities. This conceptualization of homophobia allows Pascoe's theory to address structural homophobia as the context in which various kinds of sexual prejudice at the level of social interaction emerge (see also Murray 2009).

From the 1970s through the 1990s, the relationship between masculinity and homophobia appeared very straightforward. It has been supported by a broad range of methods, from purely theoretical essays like Kimmel's (1994), to theoretical work relying on in depth qualitative data and analysis like Connell $(1995,1992)$ and Pascoe $(2005,2007)$, to quantitative analysis of representative surveys documenting gendered distinctions in support for sexually prejudiced or discriminatory statements or for sexual inequality more generally. The connection between masculinity and homophobia and the enactment of homophobia by boys and men has also been discovered across a range of social institutions and settings: in schools (e.g., Mac an Gháill 1994; Nayak and Kehily 1996; Pascoe 2007; Connell 2014), families (e.g., Averett 2016; Bucher 2014; Kane 2006, 2012), religious communities (e.g., Diefendorf 2018, Ezren 2006), workplaces (e.g., Barber 2016; Paap 2006), in online interactions (Pascoe and Diefendorf 2018) and beyond.

Qualitative research - with very few exceptions - continues to document enactments of homophobia among boys and men. Representative surveys of LGBTQ Americans document widespread experiences of prejudice, harassment, discrimination, and violence. Alongside this, opinion polls and representative surveys have charted important shifts in support for sexual equality. Thus, while surveys of opinions suggest Americans are more supportive of gender and sexual minorities, representative surveys of the actual lived experiences of gender and sexual 
minorities in the U.S. are inconsistent with this shift. (See NPR/Robert Wood Johnson Foundation/Harvard T.H. Chan School of Public Health 2017 for recent data on LGBTQ Americans' experiences of violence, harassment, prejudice and discrimination and the 2015 GLSEN National School Climate Survey for data on LGBT students experiences of harassment and discrimination at school.) Making sense of this apparent paradox is an important question that requires more research. We discuss this in more detail below, and rely on the U.S. as a primary example, with discussions of how similar processes are occurring in other nations as well.

\section{The Shifting Character of Gendered Enactments of Homophobia}

How shifts in sexual inequality are related to the relationship between masculinity and homophobia is an important issue. Consider a series of questions asked on nationally representative opinion polls in the U.S. related to people's opinions about and support for sexual inequality. Both Gallup and the Pew Research Center conduct opinion polls of Americans with a variety of measures of sexual prejudice, support for sexual inequality, or beliefs about sexual inequality. Figure 3 visualizes shifts on a series of measures related to Americans' attitudes surrounding sexual inequality over the course of the $21^{\text {st }}$ century. Each of the trends charts the proportions of respondents who were supportive of sexual equality or answered questions in ways that challenge prejudice against sexual minorities.

Figure 3. Changes in Sexual Prejudice in the United States, 2000-2017

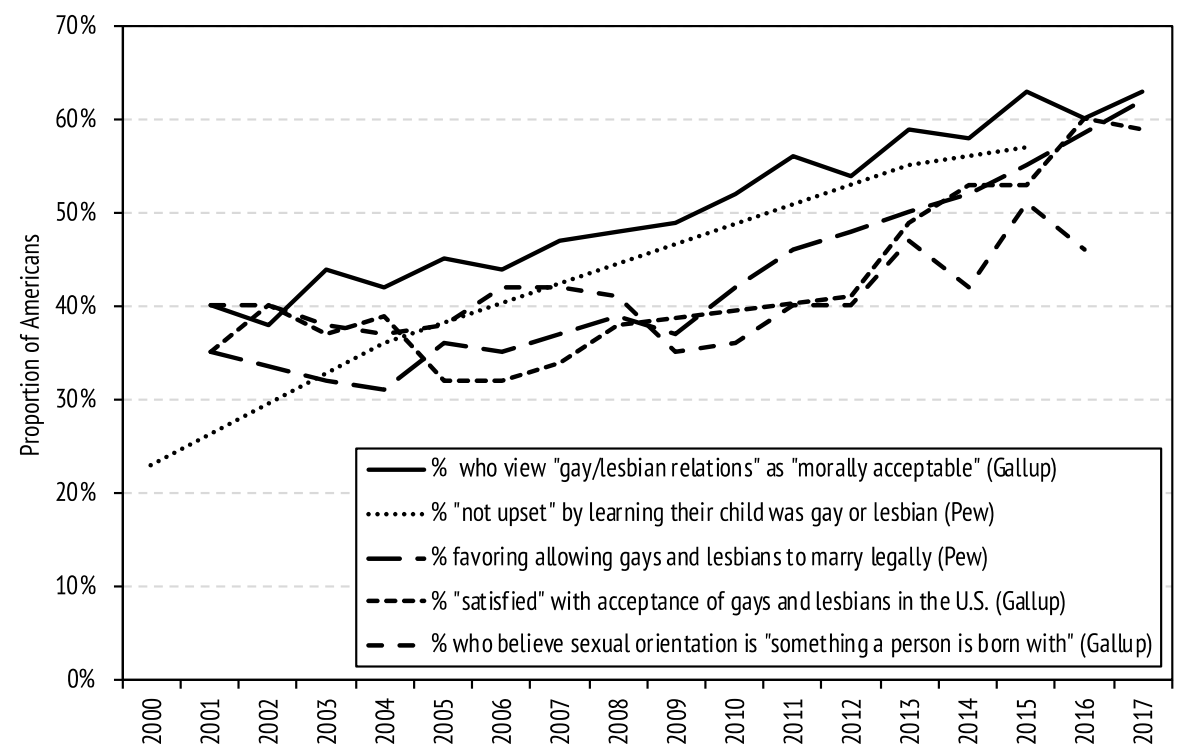

Source: Data collected from Gallup and the Pew Research Center

Figure 3 is only a sample of U.S. survey data on a selection of indicators used to study shifts in sexual prejudice and inequality. But the trends are consistent with the range of survey data available. Collectively, data like these suggest what is sometimes optimistically described as decreasing sexual prejudice and other times - following Walters (2014) — more cautiously labeled "sexual tolerance." Gradually, smaller numbers of Americans claim they would not be upset to learn that their child identified as gay or lesbian. ${ }^{2}$ Americans have dramatically changed 
their opinions about same-sex marriage. And while sociologists of sexuality often address the limits of the "born this way" discourse (e.g., Seidman 2002; Walters 2014; Ward 2011; Weeks 1986), this set of etiological beliefs about sexuality is consistent with liberal politics and support for sexual equality (Lewis 2009). And yet, as Figure 3 also illustrates, between one third and one half of Americans still respond to questions like these in ways that oppose rights and recognition for sexual minorities.

Different scholars have accounted for this apparent decline in sexual prejudice and homophobia in different ways - secularization (Hicks and Lee 2006; Hooghe and Meeusen 2013), changes in etiological beliefs about sexuality (Lewis 2009; Tygart 2000), a weakening relationship between AIDS and homosexuality (Ruel and Campbell 2006), increasing numbers of "out" gay men and lesbians (Altemeyer 2002; Seidman 2002), advances in civil liberties, and American liberalization more generally (Brooks 2000; Loftus 2001). From this perspective, things appear to be getting better, and at a rapid pace. It is important to recognize that, in most cases, these data suggest that there is support for gay rights (broadly construed here) from just over half of the U.S. population. When scholars privilege and parade these results as indicative of overall declines in sexual prejudice, the collective narrative can put forth what some scholars call out as the assumption of inevitable progress in the west (McRobbie 2009; O'Neill 2015), which may work to mask larger cultural stagnations around gender and sexual prejudice.

Indeed, while on most measures, men continue to express more sexual prejudice than women on survey data, on a very small number of indicators on some nationally representative surveys in the U.S., men have very recently begun to express less sexual prejudice than women (e.g., Saad 2010). This represents a new shift. Through questions about sexual prejudice and inequality on surveys, men have always been found to be more sexually prejudiced than women. As we addressed earlier, this was one of the early empirical findings scholars used to theorize a relationship between masculinity and homophobia in the 1970s and 80s. Shifts in these trends question the endurance of the relationship between masculinity and homophobia.

Some scholars suggest that we interpret these shifts in sexual inequality at face value, arguing that attitudinal measures collected from survey data are an illustration of the declining significance of homophobia. And a small body of qualitative research on young men has suggested that in some societies homophobia is no longer a constitutive element of masculine identities among many young men (e.g., Anderson 2009; McCormack 2012). Indeed, Anderson (2009) suggests that these shifts documented in the U.K., for example, herald a new cultural ideal for masculinity, one detached from homophobia and sexual prejudice. This "inclusive masculinity" suggests that, particularly for younger men today, masculinities are no longer organized hierarchically. Rather, Anderson (2009) argues that they are organized "horizontally," and that the acceptance of gay men implies that the connection between masculinity and homophobia has, in some societies, rapidly declined.

Among the evidence relied upon to support a decline in the relationship between masculinity and homophobia is a body of data documenting physical, quasi-sexual, and emotional closeness among heterosexual men (e.g., Anderson 2009; Anderson and McCormack 2015; McCormack 2012). This kind of "heteroflexibility" among men, some suggest, belies a deeper erosion of the relationship between masculinity and homophobia. Others, however, have been critical of the 
meanings of this behavior and of whether these shifts are actually as historically novel as they are sometimes presented. For instance, Ward (2015) documents a long history of heterosexual men touching, kissing, and sometimes having sex before and throughout the $20^{\text {th }}$ century. But, beyond this, Ward is interested in better understanding the meanings associated with the sexual fluidity of some straight white men. Among her discoveries, Ward summarizes a collection of logics she collectively refers to as "hetero-exceptionalism" that work as discursive alibis, situating white heterosexual men's same-sex sexual interactions and encounters as consistent with both masculinity and heterosexuality (see also Carrillo and Hoffman 2016, Reynolds 2015, Robinson and Moskowitz 2013, Silva 2017, Ward 2008).

Additionally, Anderson's theory of "inclusive masculinity" is not without disagreement and critique (e.g., Bridges 2014; Bridges and Pascoe 2014; de Boise 2015; O’Neill 2015). O'Neill (2015) suggests that we read Anderson and McCormack's work, and framing of their collective findings, with a focus on its relationship to a post-feminist sensibility, which is the notion that gender and sexuality equality have been achieved, and thus feminism is rendered an unnecessary political force. If we approach the body of scholarship relying on "inclusive masculinity" with this framing, we can call into question the ways this strand of work, and subsections of the field of critical masculinities studies, is complicit in positioning gender (and sexual) inequalities as "already settled" (2015:109).

Indeed, work within the "inclusive masculinity" framework has received sustained and diverse criticism. Much of this scholarship has challenged the interpretation of the data presented as evidence of a declining relationship between masculinity and homophobia or less inequality among different groups of men (e.g., Bridges 2014; Bridges and Pascoe 2014, 2018; de Boise 2015; O’Neill 2015; McDowell 2017; Allan 2018; Messerschmidt 2018; Messerschmidt and Messner 2018; Waling 2019). Allan (2018), for instance, challenges the conceptualization of "homohysteria" and "effemophobia" within the framework. Waling (2019) challenges the understanding of post-structuralism and agency at work in the framework. Similarly, de Boise (2015) argues that Anderson's (2009) theory misrepresents Connell's $(1987,1995)$ theory of gender relations, crafting a straw theory that effectively individualizes Connell's social structural theory of gender and sexual inequality (see also Messerschmidt 2018: 134-142). Similarly, Bridges and Pascoe (2014) suggest that shifts in the relationship between masculinity and homophobia are better accounted for by what they theorize as "hybrid masculinity," a framework that they situate within (rather than opposed to) Connell's $(1987,1995)$ theory of gender relations (Bridges and Pascoe 2018). Combined, these critiques highlight the problems associated with inclusive masculinity theory and its utility as a framework, which takes shifts in historically durable systems of power and inequality at face value.

Certainly, shifts in institutionalized support for sexual inequality have changed dramatically in recent history. Legislation surrounding same-sex marriage, sexual discrimination in workplaces and schools, and surrounding hate crimes and bullying increasingly exist in many societies around the world. Yet, whether these shifts are illustrations of the demise of cultural homophobia is a more difficult question to answer. Durable systems of social inequality have a tendency to transform as the foundations upon which they were reproduced are challenged (e.g., Adam 1998; Bridges and Pascoe 2014, 2018; Demetriou 2001; Tilly 1999; Walters 2014). Thus, rather than claiming uncritically that homophobia is either in decline or has declined, more scholarship has 
sought to analyze and evaluate how it has changed (e.g., Baker 2005; Bridges 2014; de Boise 2015; Pascoe 2007; Bridges and Pascoe 2018; Pascoe and Bridges 2018; Ward 2008, 2015).

Indeed, Adam (1998) called for an analysis of the ways that structures of heteronormativity and sexual inequality are "continually changing." Similarly, Murray's (2009) anthology examining homophobias cross-culturally engages with the varied "discursive logics" associated with the production and reproduction of sexual inequality around the world. Murray's work helps to illustrate the diverse and shifting logics relied upon in different national contexts that work to illustrate the varied forms. As Murray writes, "discrimination against homosexuals can be conveyed through a range of attitudes [and practices]: from indifference to dismissal, 'scientific' logic, 'tolerance,' or even a carefully delimited embrace" (2009: 3).

One way we can better understand how and why the relationship between masculinity can appear to be simultaneously eroding and expanding is to more carefully consider the various measurements scholars are using and to continue to examine how shifting beliefs and behaviors associated with homophobia are related (or not) to shifts in institutionalized and structural forms of homophobia. This should prompt a consideration of how homophobia and sexual prejudice and discrimination ought to be measured as well as whether shifts in gender and sexual inequality necessitate new measurements. For instance, Anderson (2009) and McCormack's (2012) work considers the relationship between masculinity and homophobia largely attitudinally and interpersonally. But interactional and interpersonal enactments of homophobia can operate in two different ways. For example, the interpersonal can be a site in which one works to demonstrate that they are not homophobic, which is the focus of much of Anderson and McCormack's work. However, the interpersonal is also a level of social life at which inequalities are reproduced, and often in somewhat hidden or surprising ways (Bridges and Pascoe 2014, 2018).

Further, as Connell writes, "Homophobia is not just an attitude. Straight men's hostility to gay men involves real social practice, ranging from job discrimination through media vilification to imprisonment and sometimes murder" (Connell 1995: 40). Interpersonal enactments of sexual inequality are an important site to examine the relationship between masculinity and homophobia. But they are not the only site (e.g., Adam 1998; Bridges and Pascoe 2015; Bryant and Vidal-Ortiz 2008; Mishel 2016; Murray 2009; Pascoe and Bridges 2018; Tilcsik 2011).

\section{New Methods, New Measures}

In the contemporary social world, how can we best understand shifts in interpersonal enactments of sexual inequality and institutionalized homophobia alongside a multi-dimensional relationship between masculinity and homophobia? And, when we discuss the contemporary relationship between masculinity and homophobia, are scholars always talking about the same thing? For example, one recent review of the field finds that between 1993 and 2010, 47 different approaches to measure homophobia were used (Costa, Bandeira, and Nardi 2013). In an effort to gain purchase on this dilemma and offer insights into new directions for both questions and research, we turn to two strands of work: one that seeks to further refine measurements of homophobia and another that highlights the enduring relationship between masculinity and homophobia through experimental design. Together, this scholarship suggests new 
understandings of the relationship between masculinity and homophobia alongside dramatic shifts in public support for sexual inequality. We briefly review both below and then explain how this research ought to inform our understandings of the enduring relationship between masculinity and homophobia.

Doan, Loehr, and Miller (2014) were interested in disentangling support for sexual equality from support for the less apparent forms of inequality that confer informal types of privileges upon heterosexual people and interactions. Relying on a survey experiment with nationally representative data in the U.S., Doan et al. (2014) examine the ways that Americans distinguish between what they refer to as "formal rights" and "informal privileges" in attitudes toward samesex couples. The authors find that heterosexual Americans are far more supportive of formal rights for sexual minorities (like marriage and partnership benefits) than they are of informal privileges for same-sex couples (like support for public displays of affection, for instance).

In a related study, Doan, Miller, and Loehr (2015) were interested in Americans' attitudes about love in different types of romantic couples and whether these emotional attributions to heterosexual and same-sex couples differed along gendered lines. The authors find that perceptions of love are related to granting social recognition and support for sexual equality on different measures. Gay couples, they found, were viewed as less loving than both heterosexual and lesbian couples. Indeed, lesbian couples and heterosexual couples were perceived as equally loving in their sample. And these different perceptions of how loving heterosexual, gay, and lesbian relationships are illustrate important gendered forms of sexual inequality. Importantly, these forms of inequality are more challenging to measure and might not be illustrated on most representative surveys primarily concerned with formal rights and social recognition. As Doan et al. (2014) write:

"In contrast to formal rights, informal privileges represent interactional advantages that dominant groups receive over minority groups. These advantages are not legally conferred but arise in interactional settings as a way for the dominant group to maintain superiority over minority groups." (2014: 1174-1175)

This research is consistent with a body of scholarship on what is sometimes referred to as "modern prejudice" that works to sustain a diverse collection of social inequalities based on race (e.g., Bobo 1999; Bonilla-Silva 2003) and gender (e.g., Benokratis and Feagin 1995; Jackman 1994). Scholars of modern prejudice argue that, as institutional and legal supports for inequality are challenged and become less viable mechanisms for the maintenance of durable forms of social inequality, the maintenance of inequality at the level of interaction becomes even more pertinent as among the chief mechanisms through which durable social inequalities persist. Yet, as addressed above, the relationship between interactions and the reproduction of inequality is complex - a process that unfolds in diverse, hidden, and often surprising ways.

Additionally, experimental research has also discovered that the relationship between masculinity and homophobia may have persisted despite the appearance of incredible change. A great deal of this work relies on theories of social identity arguing that people will both attempt to maintain identities that are deeply held or that are associated with social esteem (e.g., Stets and Burke 2000), but also that that people are motivated to act in specific ways to protect deeply 
held identities if they perceive them to be "threatened" (e.g., Burke and Stets 2009). When social identities that are either deeply held or associated with social esteem are threatened, people respond not simply by compensating, but overcompensating in their attempts to recover the identity. Simply put, we can learn a great deal about the various ingredients understood to comprise identities by examining what people turn to when those identities are challenged.

For example, recent work finds that men's heterosexuality is an identity easily lost when men engage in sexual activity with other men. Using a series of survey experiments, Mize and Manago (2018) find that a description of a single same-sex sexual encounter leads individuals to question the sexual orientation of a heterosexual man to a greater extent than that of a heterosexual woman when described similarly. The authors also find that when lesbian women are described as having a sexual encounter with a man, individuals are more likely to change their perceptions of the lesbian woman's sexual orientation, and again, to a greater extent than they do gay men's sexual orientation when described as having a sexual encounter with a woman. That is, when men are described as engaging in sexual activity that does not align with a sexual orientation, they are more likely to be understood to be gay, a finding that supports what Jane Ward (2007) labeled the "one act rule" of homosexuality among men (see also Schilt and Westbrook 2009). For women, these results indicated the opposite.

Scholars have similarly examined patterned reactions men have to having their masculinity experimentally "threatened" or called into question, ${ }^{3}$ examining patterned reactions to recover the identity. Munsch and Willer (2012) found that men whose self-perception of their own masculinity has been threatened are more likely espouse attitudes supportive of sexual coercion and violence. Willer et al. (2013) discovered that men react to masculinity threat by being more supportive of war and violence as well as male supremacist statements. But they also discovered that men who perceived their gender identities had been threatened were more likely to express prejudice toward homosexuality and gay men (Willer et al., 2013).

These are, of course, atypical conditions under which men are taking a survey, which help explain their discoveries. Munsch and Gruys (2018) interview young men on their reported experiences of masculinity threat to turn the focus away from the compensatory responses outlined above, and still find that men's narratives implicitly call for the subordination of women and other men. The authors use "emasculation accounts" to show that even when young men espouse egalitarian gendered and non-homophobic beliefs, when asked about threats to their masculinity the young men give examples about threats to their heterosexual intimate relationships, such as a loss of a breadwinner status, or concerns about not being understood as intelligent, appropriately attractive (strong), not being athletic enough, or being mistaken as gay. Taken together, the responses in this body of research suggest that the relationship between masculinity and homophobia can endure even when some measures seem to suggest it is in decline. Indeed, as Herek wrote in an early study, "We can reconcile the different findings of public opinion polls and social psychological studies if we recognize each method's strengths and weaknesses" (1986: 564). This body of scholarship collectively underscores the need to consider the various ways we can seek to understand the connections between masculinity and homophobia and modern prejudice, even in the wake of what sometimes appear to be massive shifts in public opinion. The relationship between masculinity and homophobia is multi-faceted, 
and as scholars, we must pay attention to the entirety of its social elements when discussing change.

\section{Conclusion}

Documenting whether and how the relationship between masculinity and homophobia is declining or enduring is a difficult task. A great deal of scholarship treats this relationship as though it can only - or is best - measured in a single way. We argue, however, that scholars studying this relationship ought to continue to consider Connell's $(1987,1995)$ multidimensional understanding of the various ways this relationship can exist. Similarly, both Kite (1984) and Herek (1986) suggested early on that we carefully scrutinize the various tools we use to measure the existence and scope of this relationship. A great deal of theory within masculinities studies more generally suggests that we remember to consider the fact that as durable forms of inequality shift, decline, and are called into question, we need theories able to capture these transformations. Those best able to account for shifts in durable systems of inequality like these anticipate change (e.g., Adam 1998; Bridges 2014; Bridges and Pascoe 2014, 2018; Connell 1987, 1995; Demetriou 2001; Murray 2009; Pascoe and Bridges 2018).

It is premature to suggest that the relationship between masculinity and homophobia be confined to the waste bin of history. But scholars need to be more explicit about how practices are connected with structural forms of sexual inequality. Emergent configurations of masculinity that appear to have new relationships with sexual prejudice should be critically examined to understand both what individuals make of these relationships, as well as whether and how they offer any real challenges to structural or institutional forms of sexual inequality. Appreciating the endurance of this relationship requires recognizing homophobias as multi-dimensional and capable of dramatic shifts. And this appreciation will require more research and a diversity of theories asking how sexual inequality is connected with masculinity structurally and interactionally in distinct ways with distinct consequences. The tasks moving forward are not only to ask if and how masculinities continue to be related to homophobia, but to also consider what forms of homophobia are being perpetuated and how. This will require the recognition that gender and sexuality inequality are often simultaneously being challenged and reproduced.

\section{Notes}

1. In this essay, when we talk about masculinities, we are primarily referring to the gendered practices associated with individuals who identify as men. This does not downplay the importance of scholarship on female masculinities. See Halberstam (1998) for an example.

2. Homophobia is a commonly utilized term among scholars. But other scholars have echoed Pascoe's concern, suggesting that this is the wrong language to be using to describe what we are attempting to study (see Pascoe and Diefendorf 2018 for a recent example). Like "homosexuality," "homophobia" emerged among psychologists as a kind of medical diagnosis initially. Psychologist George Weinberg (1972) introduced the concept and used it to challenge the dominant framing of homosexuality as a "problem"-coining a term that helped shift the focus from gay people to those holding anti-gay views and sentiments. Other scholars suggest 
that "sexual prejudice" or "antigay hostility" might more accurately describe what is often meant when using "homophobia" (e.g., Herek 2004).

3. While parents do say they would not be upset to learn their child identified as gay or lesbian, big data research relying on Google searches associated with parental anxieties surrounding their children's same-sex sexual identities suggests that parents are more concerned about gay sons than lesbian daughters (Mishel and Caudillo 2017).

4. Messerschmidt (1999) refers to the collection of performances to which men turn when their gender identities are threatened as "masculinity resources."

\section{References}

Adam, BD (1998) Theorizing Homophobia. Sexualities 1(4): 387-404.

Allan, JA (2018) Masculinity as Cruel Optimism. NORMA 13(3-4): 175-190.

Altemeyer B (2002) Changes in Attitudes Toward Homosexuals. Journal of Homosexuality 42(2): 63-75.

Anderson E (2009) Inclusive Masculinity. London: Routledge.

Anderson E and McCormack M (2015) Cuddling and Spooning: Heteromasculinity and Homosocial Tactility among Student-Athletes. Men and Masculinities 18(2): 214-230.

Averett KH (2016) The Gender Buffet: LGBTQ Parents Resisting Heteronormativity. Gender \& Society 30(2): 189-212.

Baker P (2005) Public Discourses of Gay Men. London: Routledge.

Barber K (2016) Styling Masculinity: Gender, Class, and Inequality in the Men's Grooming Industry. New Brunswick: Rutgers University Press.

Benokratis NV and Feagin JR (1995) Modern Sexism. Upper Saddle River: Prentice Hall.

Bobo L (1999) Prejudice as Group Position. Journal of Social Issues 55(3): 445-472.

Bonilla-Silva E (2003) Racism without Racists. Lanham: Rowman and Littlefield.

Bridges T (2014) A Very "Gay" Straight?: Hybrid Masculinities, Sexual Aesthetics, and the Changing Relationship between Masculinity and Homophobia. Gender \& Society 28(1): 58-82.

Bridges T and Pascoe CJ (2014) Hybrid Masculinities: New Directions in the Sociology of Men and Masculinities. Sociology Compass 8(3): 246-258.

Bridges T and Pascoe CJ (2016) Masculinities and Post-Homophobias? In: Pascoe CJ and Bridges T (eds.) Exploring Masculinities. New York: Oxford University Press, pp. 412423.

Bridges T and Pascoe CJ (2018) On the Elasticity of Gender Hegemony. In: Messerschmidt J, Messner M, Connell R and Martin PY (eds.) Gender Reckonings. New York: NYU Press, pp. 254-274.

Britton, DM (1990) Homophobia and Homosociality: An Analysis of Boundary Maintenance. The Sociological Quarterly 31(3): 423-439.

Brooks C (2000) Civil Rights Liberalism and the Suppression of a Republican Political Realignment in the United States, 1972-1996. American Sociological Review 65(4): 483 505.

Bryant K and Vidal-Ortiz S (2008) Introduction to Retheorizing Homophobias. Sexualities 11(4): 387-396. 
Bucher J (2014) “But He Can’t Be Gay": The Relationship Between Masculinity and Homophobia in Father-Son Relationships. The Journal of Men's Studies 22(3): 222-237.

Burke PJ and Stets JE (2009) Identity Theory. New York: Oxford University Press.

Carrigan T, Connell R and Lee J (1985) Toward a New Sociology of Masculinity. Theory and Society 14(5): 551-604.

Carrillo, H and Hoffman A (2016) From MSM to heteroflexibilities: Non-exclusive straight male identities and their implications for HIV prevention and health promotion. Global Public Health 11 (7-8): 923-36.

Chen A (1999) Lives at the Center of the Periphery, Lives at the Periphery of the Center: Chinese American Masculinities and Bargaining with Hegemony. Gender \& Society 13(5): 584-607.

Chauncey G (1994) Gay New York. New York: Basic Books.

Connell C (2014) School's Out: Gay and Lesbian Teachers in the Classroom. Berkeley: University of California Press.

Connell C (2016) Contesting Racialized Discourses of Homophobia. Sociological Forum 31(3): 599-618.

Connell R (1987) Gender and Power. Stanford: Stanford University Press.

Connell R (1992) A Very Straight Gay: Masculinity, Homosexual Experience, and the Dynamics of Gender. American Sociological Review 57(6): 735-751.

Connell R (1995) Masculinities. Stanford: Stanford University Press.

Connell R, Davis MD and Dowsett GW (1993) A Bastard of a Life: Homosexual Desire and Practice among Men in Working-class Milieux. Australian and New Zealand Journal of Sociology 29(1): 112-135.

Corbett K (2001) Faggot = Loser. Studies in Gender and Sexuality 2(1): 3-28.

Costa AB, Bandeira DR and Nardi HC (2013) Systematic review of instruments measuring homophobia and related constructs. Journal of Applied Social Psychology, 43(6): 13241332.

de Boise S (2015) I'm Not Homophobic, "I've Got Gay Friends": Evaluating the Validity of Inclusive Masculinity. Men \& Masculinities 8(13): 318-339.

Demetriou D (2001) Connell's Concept of Hegemonic Masculinity: A Critique. Theory and Society 30(3): 337-361.

Diefendorf S (2018) Evangelical Sexual Politics in Trump's America. PhD Dissertation, The University of Washington. Research Works. http://hdl.handle.net/1773/42547

Doan L, Loehr A and Miller LR (2014) Formal Rights and Informal Privileges for Same-Sex Couples. American Sociological Review 79(6): 1172-1195.

Doan L, Loehr A and Miller LR (2015) The Power of Love: The Role of Emotional Attributions and Standards in Heterosexuals' Attitudes toward Lesbian and Gay Couples. Social Forces 94(1):401-425.

Epprecht, M (2013) Sexuality and Social Justice in Africa: Rethinking Homophobia and Forging Resistance. London: Zed Books.

Ezren T (2006) Straight to Jesus. Berkeley: University of California Press.

Flood, M and Hamilton C (2005) Mapping Homophobia in Australia. Australia Institute Webpaper, pp. 1-15. Available online: http://www.glhv.org.au/files/aust_inst_homophobia_paper.pdf (accessed November 20, 2018) 
GLSEN. (2015) The 2015 National School Climate Survey. New York, NY. Available at: https://www.glsen.org/sites/default/files/GLSEN\%202015\%20National\%20School\%20Cl imate\%20Survey\%20\%28NSCS\%29\%20-\%20Executive\%20Summary.pdf

Greenberg D (1988) The Construction of Homosexuality. Chicago: Chicago University Press. Herek G (1986) On Heterosexual Masculinity. American Behavioral Scientist 29(5): 563-577. Herek G (2002) Gender Gaps in Public Opinion about Lesbians and Gay Men. Public Opinion Quarterly 66(1): 40-66.

Herek G (2004) Beyond "Homophobia": Thinking about Sexual Prejudice and Stigma in the Twenty-First Century. Sexuality Research \& Social Policy 1(2): 6-24.

Hicks G and Lee T (2006). Public Attitudes Toward Gays and Lesbians. Journal of Homosexuality 51(2): 57-77.

Hooghe M and Meeusen C (2013) Is Same-Sex Marriage Legislation Related to Attitudes Toward Homosexuality? Sexuality Research and Social Policy 10(4): 258-268.

Ibson J (2002) Picturing Men. London: Smithsonian Institution Press. Jackman M (1994) The Velvet Glove: Paternalism and Conflict in Gender, Class and Race. Berkeley: University of California Press.

Kane E (2006) "No Way My Boys Are Going to Be Like That!": Parents' Responses to Children's Gender Nonconformity. Gender \& Society 20(2):149-176.

Kane E (2012) The Gender Trap. New York: NYU Press.

Katz JN (1990) The Invention of Heterosexuality. Sociologist Review 20: 734.

Kimmel MS (1994) Masculinity as Homophobia. In: Brod H and Kaufman M (eds.) Theorizing Masculinities. Thousand Oaks: Sage Publications, pp. 119-141.

Kimmel MS (2012) Manhood in America, third edition. New York: Oxford University Press.

King JL (2004) On the Down Low: A Journey into the Lives of Straight Black Men Who Sleep with Men. New York: Broadway Books.

Kite ME (1984) Sex Differences in Attitudes toward Homosexuals: A Meta-Analytic Review. Journal of Homosexuality 10(1-2): 69-81.

Kite ME and Whitley, Jr BE (1996) Sex Difference in Attitudes Toward Homosexual Persons, Behaviors, and Civil Rights: A Meta-analysis. Personality and Social Psychology Bulletin 22(4): 336-353.

LaMar L and Kite ME (1998) Sex Differences in Attitudes toward Gay Men and Lesbians: A Multidimensional Perspective. The Journal of Sex Research 35(2): 189-196.

Lehne GK (1976) Homophobia Among Men. In David D and Brannon R (eds.) The Forty-Nine Percent Majority. Reading, MA: Addison-Wesley, pp. 68-88.

Lehne GK (1989) Homophobia Among Men. In: Kimmel MS and Messner MA (eds.) Men's Lives. New York: Macmillan, pp. 416-429.

Lewis GB (2009) Does Believing Homosexuality is Innate Increase Support for Gay Rights? Policy Studies Journal 37(4): 669-693.

Lipman-Blumen J (1976) Toward a Homosocial Theory of Sex Roles. Sexualities 1(3): 15-31.

Loftus J (2001) America's Liberalization in Attitudes toward Homosexuality, 1973-1998. American Sociological Review 66(5): 762-782.

Mac an Gháill, M (1994) The Making of Men. Buckingham: Open University Press.

M'baye, B. (2013) The Origins of Senegalese Homophobia. African Studies Review 56(2): 109_ 28.

McCormack M (2012) The Declining Significance of Homophobia. New York: Oxford University Press. 
McDowell, AD (2017) Aggressive and Loving Men: Gender Hegemony in Christian Hardcore Punk. Gender \& Society 31(2): 223-244.

McRobbie, A (2009) The Aftermath of Feminism. London: Routledge.

Messerschmidt JW (1999) Nine Lives: Adolescent Masculinities, the Body, and Violence. Boulder: Westview Press.

Messerschmidt JW (2018) Hegemonic Masculinity: Formulation, Reformulation, and Amplification. Lanham, MD: Rowman \& Littlefield.

Messerschmidt JW and Messner MA (2018) Hegemonic, Nonhegemonic, and "New" Masculinities. In: Messerschmidt J, Messner M, Connell R and Martin PY (eds.) Gender Reckonings. New York: NYU Press, pp. 35-56.

Mishel E (2016) Discrimination against Queer Women in the U.S. Workforce: A Résumé Audit Study. Socius 2: 1-13.

Mishel E and Caudillo ML (2017) Google Searches Show More Worry over Gay Men and Boys than over Gay Women and Girls. Contexts (blog), November 8, 2017. Available at: https://contexts.org/blog/google-searches-show-more-worry-over-gay-men-and-boysthan-over-gay-women-and-girls/

Mize TD and Manago B (2018) Precarious Sexuality: How Men and Women Are Differentially Categorized for Similar Sexual Behavior. American Sociological Review 83(2): 305-330. Mosse GL (1996) The Image of Man. New York: Oxford University Press.

Munsch C and Willer R (2012) The Role of Gender Identity Threat in Perceptions of Date Rape and Sexual Coercion. Violence Against Women 18(10): 1125-1146.

Munsch C and Gruys K (2018) What Threatens, Defines: Tracing the Symbolic Boundaries of Contemporary Masculinity. Sex Roles, online ahead of print. Available at: https://link.springer.com/content/pdf/10.1007\%2Fs11199-017-0878-0.pdf

Murray DAB (2009) Homophobias. Durham: Duke University Press.

Nayak, A and Kehily M (1996) Playing it Straight: Masculinities, Homophobia and Schooling. Journal of Gender Studies 5(2): 211-229.

NPR/Robert Wood Johnson Foundation/Harvard T.H. Chan School of Public Health (2017) Discrimination in America: Experiences and Views of LGBTQ Americans. Available at: https://www.npr.org/documents/2017/nov/npr-discrimination-lgbtq-final.pdf

O’Neill R (2015) Whither Critical Masculinity Studies? Notes on Inclusive Masculinity Theory, Postfeminism, and Sexual Politics. Men \& Masculinities 18(1): 100-120.

Paap K (2006) Working Construction: Why White Working-Class Men Put Themselves-And the Labor Movement - In Harm's Way. Ithaca: IRL Press.

Pascoe CJ (2005) "Dude, You're a Fag": Adolescent Masculinity and the Fag Discourse. Sexualities 8(3): 329-346.

Pascoe CJ (2007) Dude, You're a Fag: Masculinity and Sexuality in High School. Berkeley: University of California Press.

Pascoe CJ and Diefendorf S (2018) No Homo: Gendered Dimensions of Homophobic Epithets Online. Sex Roles, online ahead of print. Available at: https://link.springer.com/content/pdf/10.1007\%2Fs11199-018-0926-4.pdf

Pascoe CJ and Bridges T (2018) Fag Discourse in a Post-Homophobic Era. In: Grusky D and Hill J (eds.) Inequality in the $21^{\text {st }}$ Century. Boulder: Westview Press, pp. 352-358.

Pew Research Center (2017) Changing Attitudes on Gay Marriage. Pew Research Center, Religion \& Public Life, June 26. Available at: http://www.pewforum.org/factsheet/changing-attitudes-on-gay-marriage/ 
Plummer DC (2001) The Quest for Modern Manhood. Journal of Adolescence 24(1): 15-23.

Puar J (2007) Terrorist Assemblages. Duram: Duke University Press.

Puar J (2013) Rethinking Homonationalism. International Journal of Middle East Studies 45(2): 336-339.

Reynolds, C (2015) "I am Super Straight and I Prefer You Be Too": Constructions of Heterosexual Masculinity in Online Personal Ads for "Straight" Men Seeking Sex with Men. Journal of Communication Inquiry 39(3): 213-31.

Rich, A. (1980). Compulsory heterosexuality and lesbian existence. Signs 5(4): 631-660.

Robinson, B and Moskowitz D (2013) The Eroticism of Internet Cruising as a Self-Contained Behavior. Culture, Health \& Sexuality 15(5): 555-69.

Ruel E and Campbell RT (2006) Homophobia and HIV/AIDS: Attitude Change in the Face of an Epidemic. Social Forces 84(4): 2167-2178.

Saad L (2010) Americans' Acceptance of Gay Relations Crosses the 50\% Threshold. GALLUP News, May 25. Available at: http://news.gallup.com/poll/135764/Americans-AcceptanceGay-Relations-Crosses-Threshold.aspx

Schilt K and Westbrook L (2009) Doing Gender, Doing Heteronormativity: "Gender Normals," Transgender People, and the Social Maintenance of Heterosexuality. Gender \& Society 23: 440-464.

Schwartz J (2010) Investigating Differences in Public Support for Gay Rights Issues. Journal of Homosexuality 57(6): 748-759.

Seidman S (2002) Beyond the Closet. New York: Routledge.

Silva T (2017) Bud-Sex: Constructing Normative Masculinity among Rural Straight Men that Have Sex with Men. Gender \& Society 31(1): 51-73.

Stets JE and Burke PJ (2000) Identity Theory and Social Identity Theory. Social Psychology Quarterly 63: 224-237.

Tilcsik A (2011) Pride and Prejudice: Employment Discrimination against Openly Gay Men in the United States. American Journal of Sociology 117(2): 586-626.

Tilly C (1999) Durable Inequality. Berkeley: University of California Press.

Tygart CE (2000) Genetic Causation Attribution and Public Support of Gay Rights. International Journal of Public Opinion Research 12(3): 259-275.

Waling, A. (2019) Rethinking Masculinity Studies: Feminism, Masculinity and Poststructural Accounts of Agency and Emotional Reflexivity. Journal of Men's Studies 27(1): 89-107.

Walters S (2014) The Tolerance Trap. New York: NYU Press.

Ward J (2007) Straight Dude Seeks Same: Mapping the Relationship between Sexual Identities, Practices, and Cultures. In: Stombler M, Baunauch DM, Burgess EO and Donnelly D (eds.) Sex Matters, 2nd ed. New York: Allyn \& Bacon, pp. 31-37.

Ward J (2008) Dude-Sex: White Masculinities and "Authentic" Heterosexuality among Dudes Who Have Sex with Dudes. Sexualities 11(4): 414-434.

Ward J (2011) No One in Born Gay (or Straight): Here are 5 Reasons Why. Feminist Pigs (blog), November 4. Available at: http://feministpigs.blogspot.com/2011/11/no-one-is-born-gayor-straight-here-are.html

Ward J (2015) Not Gay: Sex Between Straight White Men. New York: NYU Press.

Weeks J (1986) Sexuality. London: Horwood and Tavistock.

Weinberg G (1972) Society and the Healthy Homosexual. New York: St Martin's Press.

Willer R, Rogalin C, Conlon B and Wojnowicz M (2013) Overdoing Gender: A Test of the Masculine Overcompensation Thesis. American Journal of Sociology 118(4): 980-1022. 